\title{
ANALISIS PENGARUH KECERDASAN EMOSIONAL DAN KECERDASAN SPIRITUAL TERHADAP KINERJA AUDITOR PADA PERUSAHAAN INDUSTRI DI BANDAR LAMPUNG.
}

(Study Kasus pada Perusahaan Industri di Bandar Lampung)

\author{
Nuria Erisna, Universitas Bandar Lampung \\ Ines Genevine, Universitas Bandar Lampung \\ Riswan, Universitas Bandar Lampung
}

\begin{abstract}
The purpose of this study is to determine how much influence emotional intelligence(EQ) and spiritual intelligence (SQ) on the performance of the auditor either partially or simultaneously on industrial companies in Sydney which is the object of this research. And of the two independent variables will also be sought where the dominant variable affecting the performance of auditors.

This study uses a causal research design that studies the relationship between the number of variables in which the independent variables in the study is emotional intelligence $(X 1)$ and spiritual intelligence (X2), the dependent variable is the performance of the auditor (Y). Source of data used are primary data with a questionnaire method of data collection, amounting to 30 items, which are distributed to 25 respondents (auditor).

The results show that emotional intelligence and spiritual intelligence significant positive effect on the performance of auditors in industrial enterprises in Bandar Lampung. The better the emotional and spiritual intelligence, the better the performance of the auditor. Emotional and spiritual intelligence contributes to the performance of the auditor is $73.9 \%$ while the remaining $26.1 \%$ is determined by other factors.
\end{abstract}

Keywords : Emotional Intelligence, Spiritual Intelligenc, Performance Auditor

\section{LATAR BELAKANG}

Memasuki abad 21, legenda atau paradigma lama tentang anggapan bahwa IQ (Intelligence Quotint) sebagai satu-satunya tolak ukur kecerdasan, yang juga sering dijadikan parameter keberhasilan dan kesuksesan kinerja Sumber Daya Manusia, digugurkan oleh munculnya konsep atau paradigma kecerdasan lain yang ikut menentukan terhadap kesuksesan dan keberhasilan seseorang dalam hidupnya.

Kecerdasan spiritual dan pengaruhnya terhadap kinerja dalam perusahaan: Menurt Agustian (2001) membahas tentang pengaruh kombinasi kecerdasan emosional dan spiritual yang dilandaskan pada nilai nilai keislaman dalam membentuk kepribadian dan kinerja yang sukses dengan kecerdasan emosional dan serta kecerdasan spiritual yang baik, seseorang dapat berbuat tegas mampu membuat keputusan yang baik walaupun dalam keadaan tertekan. Selain itu dengan kecerdasan emosional, seseorang juga dapat menunjukkan integritasnya. Orang dengan kecerdasan emosional dan kecerdasan spiritual yang baik mampu berfikir 
jernih walaupun dalam tekanan, bertindak sesuai etika, berpegang pada prinsip dan memiliki dorongan berprestasi. Selain itu orang yang memiliki kecerdasan emosional dan kecerdasan spiritual mampu memahami perspektif atau pandangan orang lain dan dapat mengembangkan hubungan yang dapat dipercaya.

Guna menunjang profesionalismenya sebagai auditor perlu meningkatkan kualitas, profesionalisme dan akuntabilitas dalam menjalankan aktivitasnya, diperlukan audit yang tidak hanya terbatas pada keuangan dan kepatuhan saja, tetapi harus diperluas dengan meningkatkan kualitas dan kinerja auditor organisasi itu sendiri.

Menurut Arens, (1995) auditor adalah seseorang yang menyatakan pendapat atas kewajaran dalam semua hal yang material, posisi keuangan hasil usaha dan arus kas yang sesuai dengan prinsip akuntansi berlaku umum di Indonesia. Tanpa adanya pengendalian atau kematangan emosi dan keyakinan terhadap Tuhan Yang Maha Esa (keimanan dan ketakwaan), sangat sulit bagi seorang auditor untuk dapat bertahan dalam menghadapi tekanan frustasi, stress, menyelesaikan konflik yang sudah menjadi bagian atau resiko profesi, dan memikul tanggung jawab seperti apa yang disebutkan dalam Pedoman Kode Etik Akuntan Indonesia, serta untuk tidak menyalahgunakan kemampuan dan keahlian yang merupakan amanah yang dimilikinya kepada jalan yang tidak dibenarkan. Sehingga akan berpengaruh terhadap hasil kinerja mereka (mutu dan kualitas audit) atau terjadinya penyimpangan-penyimpangan, kecurangan dan manipulasi terhadap tugas yang diberikan. Karena seseorang yang memiliki kecerdasan emosional yang baik akan mampu untuk mengetahui serta menangani perasaan mereka dengan baik, mampu untuk menghadapi perasaan orang lain dengan efektif. Selain itu juga seorang akuntan yang memiliki pemahaman atau kecerdasan emosi dan tingkat religiusitas yang tinggi akan mampu bertindak atau berperilaku dengan etis dalam profesi dan organisasi (Ludigdo dan Maryani, 2001).

Kemampuan mempertanggungjawabkan (akuntabilitas) dari sektor publik pemerintah sangat tergantung pada kualitas audit organisasi tersebut. Tanpa kualitas audit yang baik, maka akan timbul permasalahan, seperti munculnya kecurangan, korupsi, kolusi dan berbagai ketidakberesan di pemerintah. Oleh karena sesuai saran penelitian sebelumnya, perlu dilakukan pengujian ulang atas responden pada kantor yang berbeda sebagai upaya dalam menguji kembali atas penelitian pengaruh kecerdasan emosional dan kecerdasan spiritual terhadap kinerja.

\section{TELAAH LITERATUR DAN PENGEMBANGAN HIPOTENSI}

\section{Kecerdasan Emosional (Emotional Quotient)}

Menurut Mayer (2007 : 58) kecerdasan emosional juga diartikan suatu kemampuan khusus membaca perasaan terhadap orang yang melakukan kontak, dan menangani relasi secara efektif. Indikator dari Kecerdasan emosional yaitu: Kesadaran diri, Pengelolaan diri, Empati, Keterampilan social, Motivasi diri (Robbins, 2008 : 151).

1. Kesadaran diri, kemampuan untuk menyadari apa yang dirasakan.

2. Pengelolaan diri, kemampuan untuk mengelola emosi dan rangsangan sendiri.

3. Motivasi diri, kemampuan untuk bertahan dalam menghadapi kemunduran dan kegagalan.

4. Empati, kemampuan untuk merasakan bagaimana perasaan orang lain.

5. Keterampilan social, kemampuan untuk menangani emosi orang lain. Kesadaran diri adalah suatu cara memproses informasi sehingga sadar akan perasaan perilaku diri 
maupun persepsi orang lain tentang diri pribadi. Proses ini dapat dilakukan dengan memanfaatkan informasi, kepekaan, perasaan, penilaian, dan maksud diri yang disediakan oleh diri sendiri.

Menurut Zohar dan Marshall (2000 : 3) kecerdasan spiritual adalah kecerdasan untuk menghadapi dan memecahkan persoalan makna atau nilai, yaitu kecerdasan untuk menempatkanprilaku dan hidup kita dalam konteks makna yang lebih luas dan kaya, kecerdasan untuk menilai bahwa tindakan atau jalan hidup seseoang lebih bermakna dibandingkan yang lain.

Karyawan dengan SQ yang tinggi biasanya akan lebih cepat mengalami pemulihan dari suatu penyakit, baik secara fisik maupun mental. Ia lebih cepat mudah bangkit dari suatu kejatuhan atau penderitaan, lebih tahan menghadapi stress, lebih mudah melihat peluang karena memiliki sikap mental positif, serta lebih ceria, bahagia dan merasa puas dalam menjalani kehidupan. Berbeda dengan ditor yang memiliki SQ rendah. Pada orang dengan SQ rendah, keberhasilan dalam hal karir, pekerjaan, penghasilan, status dan masih banyak lagi hal-hal yang bersifat materi ternyata tidak selalu mampu membuatnya bahagia. Persaingan dan perbedaan kepentingan yang berlangsung begitu ketat sering kali membuat manusia kehilangan arah dan identitas. Indikator dari Kecerdasan Spiritual yaitu: Konsistensi (Istiqamah) Ketulusan (Keikhlasan) (Agustian, 2001 : 199).

Kinerja auditor yang sering disebut juga prestasi kerja merupakan suatu hasil kerja secara kuantitas yang dicapai oleh seorang auditor dalam melaksanakan tugasnya sesuai dengan tugas yang dibebankan kepadanya. Menurut (Malthis dan Jackson, 2006 : 78) kinerja (performance) pada dasarnya adalah apa yang dilakukan atau yang tidak dilakukan oleh auditor. Indikator dari Kinerja Kerja yaitu: Kualitas hasil kerja, Kuantitas dari hasil, Kehadiran, Ketepatan waktu dari hasil, Kemampuan bekerjasama (Malthis\&Jackson, 2006:78).

\subsection{Kecerdasan Spiritual (Spiritual Quotient)}

Menurut Zohar dan Marshall (2000 : 3) kecerdasan spiritual adalah kecerdasan untuk menghadapi dan memecahkan persoalan makna atau nilai, yaitu kecerdasan untuk menempatkanprilaku dan hidup kita dalam konteks makna yang lebih luas dan kaya, kecerdasan untuk menilai bahwa tindakan atau jalan hidup seseoang lebih bermakna dibandingkan yang lain. SQ adalah landasan yang diperlukan untuk memfungsikan IQ dan EQ secara efektif. Bahkan menurutnya SQ merupakan kecerdasan tinggi manusia. Kecerdasan spiritual memberikan manusia moral, kemampuan menyesuaikan diri berdasarkan pengalaman dan cinta serta kemampuan setara.

SQ adalah tentang pendekatan holistik kehidupan: kegunaan, kesadaran diri, belas kasih, kreativitas, kemampuan berfikir, kemampuan untuk alasan keluar dan lain-lain secara bersama-sama. SQ melengkapi kita untuk melihat dan memecahkan masalah makna dan nilai, dan kemudian kita mulai untuk mengarah pikiran dan tindakan dalam hidup kita menuju cakrawala yang lebih luas dan bermakna. Dengan SQ, kita dapat membedakan lebih jelas yang benar dan yang salah.

Spiritualitas adalah sebuah jalur, merupakan hal yang pribadi dan personal, memiliki elemen banyak agama, dan mengarah pada pencarian diri seseorang, Spiritualitas memiliki arti bahwa orang (auditor) memiliki kehidupan personal yang berkembang dan dikembangkan dengan melakukan pekerjaan yang relevan, berarti dan menantang.

Zohar dan Marshall (2000 : 37) memberi solusi untuk meningkatkan kecerdasan spiritual dengan cara : 
1. Jalan tugas, jalan ini menghindari manusia dari prasangka jelek, pikiran sempit, kurang imajinasi, dan kurang motivasi. Melalui jalan tugas ini diharapkan tumbuh kerja sama yang harmonis dan saling memberi sumbangan pemikiran.

2. Jalan pengasuhan, jalan ini menghindarkan manusia dari sikap oportunis dan pragmatis. Ini mengajarkan manusia bagaimana bisa mendengarkan pendapat orang lain dengan baik.

3. Jalan pengetahuan, menganjurkan agar tidak sok ilmiah atau juga menjauhkan diri dari membahas hal-hal sepele yang bukan urusannya.

4. Jalan perubahan pribadi, jalan ini mengajarkan bagaimana menjadi cerdas secara spiritual adalah dengan membangkitkan dalam diri bahwa hati nurani adalan segalanya. Ia tidak pernah punya rasa bimbang dalam melaksanakan hal-hal positif. Bila jalan ini ditempuh, tidak akan ada istilah janji-janji bukti atau janji malah ditepati.

5. Jalan persaudaraan, jalan ini mengajarkan bagaimana bisa berbuat adil dan rasa hormat kepada musuh sekalipun.

6. Jalan kepemimpinan yang penuh pengabdian, mengajarkan bahwa bagaimana menghindari memanfaatkan kekuasaan demi tujuan sendiri dan tujuan-tujuan jahat lainnya. Dengan demikian akan lahir suatu pengabdian yang tulus.

\subsection{Kinerja Auditor}

\section{a. Pengertian Auditor}

Auditor adalah seseorang yang memiliki kualifikasi tertentu dalam melakukan audit atas laporan keuangan dan kegiatan suatu perusahaan atau organisasi.

\section{b. Pengertian Kinerja Auditor}

Kinerja auditor yang sering disebut juga prestasi kerja merupakan suatu hasil kerja secara kuantitas yang dicapai oleh seorang auditor dalam melaksanakan tugasnya sesuai dengan tugas yang dibebankan kepadanya. Baik atau tidaknya suatu perusahaan itu jelas tergantung pada baik tidaknya kinerja yang ada didalam organisasi menurut Hasibun (2000 : 93) memberikan batas kinerja sebagai suatu hasil kerja yang dicapai seseorang dalam menjalankan tugas-tugas yang dibebankan kepadanya yang didasarkan atas kecakapan, pengalaman, dan kesungguhan serta waktu. Prestasi kerja adalah gabungan dari tiga faktor penting yaitu kemampuan dan penerimaan atas penjelasan delegasi tugas dan peran serta tingkat motivasi seorang pekerja. Semakin tinggi ketiga faktor diatas, maka semakin besarlah prestasi kerja auditor yang bersangkutan.

Menurut (Malthis dan Jackson, 2006 : 78) kinerja (performance) pada dasarnya adalah apa yang dilakukan atau yang tidak dilakukan oleh auditor. Kinerja auditor yang umum untuk kebanyakan pekerjaan meliputi elemen sebagai berikut :

$\checkmark \quad$ Kualitas dari hasil

$\checkmark \quad$ Kuantitas dari hasil

$\checkmark$ Ketetapan waktu dari hasil

$\checkmark$ Kehadiran

$\checkmark \quad$ Kemampuan bekerja sama

Selain kemampuan dan usaha yang dimiliki oleh auditor yang bersangkutan, kinerja juga harus didukung oleh organisasi tempat auditor tersebut bekerja agar kinerjanya dapat meningkat. Salah satu dukungan yang dapat di berikan pelatihan ESQ pada auditornya. 


\section{c. Tujuan Penilaian Kinerja}

Ada sejumlah tujuan yang biasanya dapat dicapai oleh sebuah organisasi atau perusahaan dengan menerapkan sebuah Sistem Manajemen Kinerja, antara lain :

1. "Meningkatkan prestasi kerja auditor, baik secara individu maupun sebagai kelompok, sampai setinggi-tingginya dengan memberikan kesempatan pada mereka untuk memenuhi aktualisasi diri dalam rangka pencapaian tujuan perusahaan.

2. Peningkatan yang terjadi pada prestasi kerja auditor secara perorangan pada gilirannya akan mendorong kinerja sumber daya manusia secara keseluruhan, yang di seleksikan dalam kenaikan produktifitas.

3. Merangsang minat dalam pengembangan pribadi dengan tujuan meningkatkan hasil karya dan prestasi pribadi serta potensi laten auditor dengan cara memberikan umpan balik pada mereka tentang prestasi mereka.

4. Membantu auditor untuk dapat menyusun program penembangan dan pelatihan auditor yang lebih tepat guna.

5. Menyediakan alat/sarana untuk membandingkan prestasi kerja pegawai dengan tingkat gajinya atau imbalannya sebagai bagian dari kebijakan dan sistem imbalan yang baik.

6. Memberikan kesempatan pada pegawai untuk mengeluarkan perasaannya tentang pekerjaan atau hal-hal yang ada kaitannya dengan pekerjaan.

Tujuan dan kegunaan penilaian prestasi kerja karyawan menurut Hasibun (2000 : 88) adalah sebagai berikut :

1. Sebagai dasar pengambilan keputusan yang digunakan untuk promosi, demosi, pemberhentian dan penetapan besarnya balas jasa.

2. Untuk mengukur prestasi kerja yaitu sejauh mana auditor bisa sukses dalam pekerjaannya.

3. Sebagai dasar untuk mengevaluasi seluruh kegiatan didalam perusahaan.

4. Sebagai dasar untuk menentukan kebutuhan dan keefektifan jadwal kerja, metode kerja, struktur organisasi, gaya pengawasan, kondisi kerja dan peralatan kerja.

5. Sebagai indikator untuk menentukan kebutuhan akan pelatihan bagi karyawan yang berada di dalam organisasi.

6. Sebagai alat untuk meningkatkan motivasi kerja karyawan sehingga dicapai tujuan untuk mendapatkan performa kerja yang baik.

7. Sebagai alat untuk mendorong atau membiasakan para atasan (supervisor, manager, administrators) untuk observasi perilaku bawahan (subordinate) supaya diketahui minat dan kebutuhan-kebutuhan bawahannya.

8. Sebagai kriteria di dalam menentukan seleksi dan penempatan auditor.

9. Sebagai alat untuk mengidentifikasikan kelemahan-kelemahan personil, dengan demikian bisa sebagai bahan pertimbangan agar bisa diikutsertakan dalam program latihan kerja tambahan.

10. Sebagai alat untuk melihat kekurangan atau kelemahan-kelemahan di masa lampau dan meningkatkan kemampuan kerja auditor selanjutnya.

11. Sebagai alat untuk memperbaiki atau mengembangkan kecakapan auditor.

12. Sebagai dasar untuk memperbaiki dan mengembangkan uraian pekerjaan (Job Description) 


\section{METODOLOGI PENELITIAN}

\subsection{Objek Penelitian}

Penelitian ini akan dilaksanakan pada perusahaan industri yang ada di Bandar Lampung. Penulis meneliti hanya pada 10 perusahaan yaitu:

\begin{tabular}{|c|l|c|}
\hline NO & \multicolumn{1}{|c|}{ PERUSAHAAN } & JUMLAH AUDITOR \\
\hline 1 & Andatu Lestari Plywood, PT. & 2 orang \\
\hline 2 & Berindo Jaya, PT. & 3 orang \\
\hline 3 & Budi Mutu Prima, PT. & 3 orang \\
\hline 4 & Budi Sari Bumi, PT. & 3 orang \\
\hline 5 & Garuda Food Putra Putri Jaya, PT. & 3 orang \\
\hline 6 & Hanjung Indonesia, PT. & 2 orang \\
\hline 7 & Masula Agung Garbhamas, PT. & 3 orang \\
\hline 8 & Nedcoffee Indonesia Makmur Jaya, PT. & 3 orang \\
\hline 9 & Nestle Indonesia, PT. & 3 orang \\
\hline 10 & Sinar Laut, CV. & . \\
\hline
\end{tabular}

Sumber: - Data auditor dari penelitian sebelumnya (Anggraini : 2011)

\subsection{Populasi dan Sample}

\section{Populasi} Lampung.

Yang menjadi populasi dari penelitian ini adalah seluruh internal auditor di Bandar Sampel

Sampel adalah bagian dari jumlah dan karakteristik yang dimiliki oleh populasi tersebut (Sugiono, $2005: 73$ ). Adapun teknik pengambilan sampel yang penulis pilih adalah teknik random sampling (sampel secara acak). Alasan penulis menggunakan teknik ini karena keterbatasan waktu, tenaga dan dana. Karena peneliti mengambil seluruh populasi yaitu 25 auditor (responden) maka penelitian ini merupakan penelitian populasi.

\section{Jenis dan Sumber Data}

Jenis data dalam penelitian ini adalah data primer. Data primer diperoleh secara langsung dari perusahaan industri di Bandar Lampung. itu sendiri dengan melakukan penyebaran kuesioner kepada auditor yang menjadi responden.

\subsection{Metode Pengumpulan Data}

Metode pengumpulan data yang dilakukan dalam penelitian ini adalah dengan menggunakan kuesioner dengan media mail survey. Kuesioner adalah daftar pertanyaan yang harus diisi oleh responden yang akan mewakili setiap variabel penelitian yaitu variabel $\mathrm{X}_{1}$, $\mathrm{X}_{2}$, dan $\mathrm{Y}$. Untuk mengukur variabel kecerdasan emosional dan kecerdasan spiritual, maka skala yang peneliti gunakan dalam penelitian ini adalah skala Likert dimana menunjukan tingkat efektifitas variabel yang diukur dengan 5 kategori sebagai berikut :
a. SS : Sangat Sering, bobot nilai 5
b. $\quad S \quad$ : Sering, bobot nilai 4 
c. KK : Kadang-kadang, bobot nilai 3

d. SK : Sangat Kurang, bobot nilai 2

e. TP : Tidak Pernah, bobot nilai 1

Skala ini mengukur tingkat keseringan responden terhadap serangkai pernyataan yang mengukur variabel kecerdasan emosional dan spiritual. Untuk mengukur variabel kinerja karyawan,kuesioner diisi oleh pimpinan karyawan. Tetap menggunakan Skala Likert yang menunjukkan efektifitas variabel yang diukur dengan 5 kategori sebagai berikut :

a. STS : Sangat Tidak Setuju, bobot nilai 1

b. TS : Tidak Setuju, bobot nilai 2

c. BS : Biasa Saja, bobot nilai 3

d. S : Setuju, bobot nilai 4

e. SS : Sangat Setuju, bobot nila

Skala mengukur tingkat kesetujuan atau ketidaksetujuan pimpinan terhadap serangkaian pernyataan yang mengukur variabel kinerja karyawannya.

\section{Metode Analisis Data}

Untuk menganalisis seberapa besar pengaruh kecerdasan emosional dan kecerdasan spiritual terhadap kinerja auditor pada beberapa perusahaan industri di Bandar Lampung, maka digunakan langkah-langkah metode analisis data sebagai berikut.

\section{Definisi Operasional Variabel}

Agar tidak terjadi perbedaan pandangan dalam mendefinisikan variabel-variabel beserta definisi operasional nya. Definisi operasional variabel berisikan unsur-unsur dari suatu variabel, yang memungkinkan penulis mengumpulkan data yang relevan untuk variabel tersebut. Dalam penelitian ini definisi operasional variabelnya adalah sebagai berikut :

Variabel Kecerdasan Emosional $\left(\mathrm{X}_{1}\right)$

Kecerdasan emosional adalah kemampuan untuk mengenali perasaan kita sendiri dan perasaan orang lain (empati), kemampuan memotivasi diri, mengolah emosi dan membina hubungan baik dengan orang lain. Dalam penelitian ini kecerdasan emosional dibatasi pada 5 indikator, yaitu :

1. Kesadaran diri

2. Pengelolaan diri

3. Motivasi diri

4. Empati

5. Keterampilan sosial

Variabel Kecerdasan Spiritual $\left(\mathrm{X}_{2}\right)$

Kecerdasan spiritual (SQ) adalah kecerdasan untuk menghadapi dan memecahkan persoalan makna atau nilai, yaitu kecerdasan untuk menempatkan perilaku dan hidup kita dalam konteks makna yang lebih luas dan kaya, kecerdasan untuk menilai bahwa tindakan atau jalan hidup seseorang lebih bermakna dibandingkan yang lain. Dalam penelitian ini kecerdasan spiritual dibatasi pada dua indikator, yaitu :

1. Konsistensi (Istiqomah)

2. Ketulusan/sincerety (keikhlasan) 
Variabel Kinerja Auditor (Y)

Kinerja karyawan yang sering juga disebut prestasi kerja merupakan suatu hasil yang dicapai seseorang dalam menjalankan tugas-tugasnya yang dibebankan kepadanya didasarkan kecakapan, pengalaman dan kesungguhan serta waktu. Dalam penelitian ini variabel kinerja auditor dibatasi pada lima indikator yaitu :

1. Kualitas dari hasil

2. Kuantitas dari hasil

3. Ketepatan waktu dari hasil

4. Kehadiran

5. Kemampuan bekerja sama

Berdasarkan variabel penelitian yang ada dan batasan operasional variabel tersebut, akan dijadikan kuesioner. Isi dari kuesioner tersebut diadopsi dari penelitian sebelumnya (Anggraini : 2011) yang merupakan kumpulan perilaku yang di modifikasi dengan menggunakan indikator dari variabel yang akan dianalisis.

\section{ANALISIS DAN PEMBAHASAN}

\subsection{Uji Valiaditas dan Realibilitas}

\section{Uji validitas}

Uji validitas menunjukan seberapa cermat suatu alat tes melakukan fungsi ukur yang dapat mengukur apa yang ingin diukur. Dalam penelitian ini alat ukurnya berupa kuesioner yang berisi pernyataan-pernyataan yang mewakili variabel independen yakni kecerdasan emosional sebanyak 10 item pernyataan, kecerdasan spiritual sebanyak 10 item pertanyaan serta variabel independen variabel kinerja sebanyak 10 item pernyataan. Pengujian ini menggunakan program SPSS (Statistical Package For Social Science). Pengujian ini bertujuan untuk menguji apakah tiap item instrument (pernyataan) benar-benar mampu mengungkap faktor yang akan diukur (valid dan reliable). Jika tiap item pernyataan tersebut sudah valid dan reliabel, berarti item-item pernyataan tersebut sudah bisa untuk mengukur faktornya. Nilai validitas masing-masing item pernyataan dapat dilihat pada nolai Corrected item-Total Correlation masing-masing pernyataan. Bila nilai Corrected item-Total Correlation $>0.3$ maka alat ukur atau item pernyataan bersifat valid.

\section{Uji Reliabilitas}

Reliabilitas instrument adalah hasil pengukuran yang dapat dipercaya. Realibilitas instrument diperlukan untuk memanfaatkan data sesuai tujuan pengukuran. Untuk mencapai hal tersebut, dilakukan realibilitas dengan menggunakan metode Alpha Cronbach's diukur berdasarkan skala Alpha Cronbach's 0 sampai 1. Realibilitas suatukonstruk variabel dikatakan baik jika memiliki nilai Alpha Cronbach's > 0,60 (Sujianto, 2007 : 92).

\section{Uji Asumsi Klasik}

Model regresi linier berganda (multiple regression) dapat disebut sebagai model yang baik jika model tersebut memenuhi beberapa asumsi yang kemudian disebut dengan asumsi klasik. Proses pengujian asumsi klasik dilakukan bersama dengan proses uji regresi sehingga langkah-langkah yang dilakukan dalam pengujian asumsi klasik menggunakan langkah kerja yang sama dengan uji regresi. Ada beberapa uji asumsi yang harus dilakukan terhadap suatu 
model regresi tersebut yaitu uji normalitas, uji autokorelasi, uji multikolintaritas, dan uji heteroskedastitas.

\section{Uji Normalitas}

Uji Normalitas bertujuan untuk mengetahui apakah variabel pengganggu atau residual memiliki distribusi normal. Sebagai dasar bahwa uji t dan uji F mengasumsikan bahwa nilai residual mengikuti distribusi normal. Jika asumsi ini dilanggar maka model regresi dianggap tidak vaild dengan jumlah sampel yang ada. Jika jumlah sampel sedikit dan jenis data adalah nominal atau ordinal maka metode yang digunakan adalah statistik non parametrik. Menurut Nana Sudjana, uji normalitas data dilakukan dengan menggunakan uji Liliefors (Lo) dengan penentuan taraf sigifikansi, yaitu pada taraf signifikasi $5 \%(0,05)$.

\section{Uji Miltikolinieritas}

Uji Multikolinieritas bertujuan untuk menguji apakah model regresi ditemukan adanya korelasi antar variabel bebas (independen variabel). Model regresi yang baik seharusnya tidak terjadi korelasi diantara variabel bebas, karena jika hal tersebut terjadi maka variabel-variabel tersebut tidak orthogonal atau terjadi kemiripan. Variabel orthogonal adalah variabel bebas yang nilai korelasi antar sesama variabel bebas bernilai nol. Uji ini untuk menghindari kebiasaan dalam proses pengambilan keputusan mengenai pengaruh parsial masing-masing variabel independen terhadap variabel dependen. Untuk mendeteksi apakah yang terjadi problem multikol dapat melihat nilai torerance dan lawannya Variance Inflation Factor (VIF). Sujianto (2007 : 73) mengatakan jika nilai variance inflation Factor (VIF) tidak lebih dari 10 maka model terbebas dari miltikolinieritas.

\section{Uji heteroskedastisitas}

Uji heteroskedastisitas bertujuan menguji apakah dalam model regresi terjadi ketidak samaan variance dari residual satu pengamatan ke pengamatan yang lain. Jika variance tetap, maka disebut homoskedastisitas dan jika berbeda maka terjadi problem heteroskedastisitas. Untuk mendeteksi ada tidaknya heterositas pada suatu model dapat dilihat dari pola gambar scatter plot model tersebut. Menurut Sujianto (2007 : 73), tidak terdapat heteroskedastisitas jika :

1) Penyebaran titik-titik data sebaiknya tidak berpola

2) Titik-titik data menyebar diatas dan dibawah atau disekitar angka 0 , dan

3) Titik-titik data tidak mengumpul hanya di atas atau di bawah saja.

\section{Teknik Analisis}

Teknik analisis yang digunakan dalam penelitian ini adalah dengan menggunakan analisis kualitatif dan analisis kuantitatif, analisis kualitatif berupa tabel yang menjelaskan tanggapan responden tentang pertanyaan yang ada di kuesioner, kuantitatif untuk memberikan gambaran dan menjawab perumusan masalah. Data yang diperoleh dari kuesioner akan dianalisis dengan menggunakan analisis statistik yaitu dengan menggunakan analisis regresi linier berganda yang terstandarisasi dan dihitung menggunakan program SPSS (Statistical Package For Social Science) dari program komputer untuk mengukur pengaruh kecerdasan emosional dan kecerdasan spiritual terhadap kinerja auditor.

Untuk mengetahui seberapa besar pengaruh kecerdasan emosional dan kecerdasan spiritual terhadap kinerja auditor serta untuk mengetahui variabel mana diantara kecerdasan 
emosional dan kecerdasan spiritual yang lebih mempengaruhi tingkat kinerja auditor digunakan rumus regresi linier berganda :

$$
\mathbf{Y}=\mathbf{a}+\mathbf{b}_{1} \mathbf{X}_{1}+\mathbf{b}_{2} \mathbf{X}_{2}+\mathbf{e}
$$

Dimana :

Y : Kinerja auditor

A : Konstanta

$\mathrm{b}_{1}, \mathrm{~b}_{2} \quad$ : Koefisien regresi

$\mathrm{X}_{1} \quad$ : Kecerdasan Emosional

$\mathrm{X}_{2} \quad$ : Kecerdasan spiritual

e : Standar error

Rekapitulasi hasil pernyataan terhadap Variabel Kecerdasan Emosional pada perusahaan industri di Bandar Lampung

Tabel 1 Pernyataan tentang Kecerdasan Emosional

\begin{tabular}{|c|l|c|c|c|c|}
\hline No. & \multicolumn{1}{|c|}{ Pertanyaan } & Max & Riil & $\%$ & Kategori \\
\hline 1 & $\begin{array}{l}\text { Dalam melakukan audit, saya selalu mengambil } \\
\text { keputusan dengan bijaksana dan tidak tergesa-gesa. }\end{array}$ & 125 & 105 & 84 & $\begin{array}{c}\text { Sangat } \\
\text { Setuju }\end{array}$ \\
\hline 2 & Saya menyadari kekurangan yang ada pada diri saya. & 125 & 99 & 79,2 & Setuju \\
\hline 3 & $\begin{array}{l}\text { Saya dapat menenangkan diri dan mengontrol } \\
\text { prilaku, pada saat saya emosi. }\end{array}$ & 125 & 94 & 75,2 & Setuju \\
\hline 4 & $\begin{array}{l}\text { Saya tidak membawa masalah pribadi (di luar kantor) } \\
\text { ke dalam lingkungan kerja, sehingga berpengaruh } \\
\text { terhadap pekerjaan saya. }\end{array}$ & 125 & 88 & 70,4 & Setuju \\
\hline 5 & $\begin{array}{l}\text { Dalam kondisi kerja apapun, saya tetap merasa } \\
\text { optimis dan tetap memberikan yang terbaik dalam } \\
\text { pekerjaan saya. }\end{array}$ & 125 & 108 & 86,4 & $\begin{array}{l}\text { Sangat } \\
\text { Setuju }\end{array}$ \\
\hline 6 & $\begin{array}{l}\text { Saya memiliki kegigihan untuk mencoba lagi } \\
\text { walaupun pernah mengalami kegagalan dalam } \\
\text { melakukan tugas. }\end{array}$ & 125 & 105 & 84 & $\begin{array}{l}\text { Sangat } \\
\text { Setuju }\end{array}$ \\
\hline 7 & $\begin{array}{l}\text { Saya memahami dan mengerti tugas serta kesibukan } \\
\text { orang lain. }\end{array}$ & 125 & 108 & 86,4 & $\begin{array}{l}\text { Sangat } \\
\text { Setuju }\end{array}$ \\
\hline 8 & $\begin{array}{l}\text { Saya memperhatikan kepentingan orang lain, ketika } \\
\text { mereka membutuhkan bantuan. }\end{array}$ & 125 & 108 & 86,4 & $\begin{array}{l}\text { Sangat } \\
\text { Setuju }\end{array}$ \\
\hline 9 & $\begin{array}{l}\text { Saya mampu bekerja secara tim dengan personil yang } \\
\text { berubah-ubah untuk mencapai tujuan. }\end{array}$ & 125 & 109 & 87,2 & $\begin{array}{l}\text { Sangat } \\
\text { Setuju }\end{array}$ \\
\hline 10 & $\begin{array}{l}\text { Saya berkomunikasi dengan sesama auditor untuk } \\
\text { menjaga keharmonisan hubungan antar rekan kerja. }\end{array}$ & 125 & 108 & 86,4 & $\begin{array}{l}\text { Sangat } \\
\text { Setuju }\end{array}$ \\
\hline
\end{tabular}

\section{Keterangan :}

$0,00 \%-20,00 \%$

$20,01 \%-40,00 \%$

$=$ Sangat Tidak Setuju

$40,01 \%-60,00 \%$

$=$ Tidak Setuju

$60,01 \%-80,00 \%$

= Biasa Saja

$80,01 \%-100,00 \%$

$=$ Setuju

$=$ Sangat Setuju 


\section{Rekapitulasi hasil pernyataan terhadap Variabel Kecerdasan Spiritual pada perusahaan industri di Bandar Lampung}

Tabel 2 Pernyataan tentang Kecerdasan Spiritual

\begin{tabular}{|c|c|c|c|c|c|}
\hline No. & Pertanyaan & Max & Riil & $\%$ & Kategori \\
\hline 1 & $\begin{array}{l}\text { Saya mengungkapkan temuan yang perlu saya } \\
\text { sampaikan dalam mengaudit kepada pihak yang } \\
\text { bersangkutan. }\end{array}$ & 125 & 112 & 89,6 & $\begin{array}{l}\text { Sangat } \\
\text { Setuju }\end{array}$ \\
\hline 2 & $\begin{array}{l}\text { Dalam hal imbal jasa, saya tidak memanfaatkan } \\
\text { keahlian saya hanya untuk kepentingan pribadi saya. }\end{array}$ & 125 & 102 & 81,6 & $\begin{array}{l}\text { Sangat } \\
\text { Setuju }\end{array}$ \\
\hline 3 & $\begin{array}{l}\text { Saya menyampaikan secara langsung dan terbuka } \\
\text { mengenai hal-hal yang menurut saya tidak berkenan. }\end{array}$ & 125 & 94 & 75,2 & Setuju \\
\hline 4 & $\begin{array}{l}\text { Saya menyampaikan langsung kepada pihak yang } \\
\text { bersangkutan, apabila hasil kerja dari rekan satu tim } \\
\text { kurang/tidak berkenan. }\end{array}$ & 125 & 76 & 60,8 & Setuju \\
\hline 5 & $\begin{array}{l}\text { Saya mengakui kelebihan yang saya miliki dan } \\
\text { memberikan bantuan pada rekan kerja dengan } \\
\text { kelebihan yang saya miliki. }\end{array}$ & 125 & 90 & 72 & Setuju \\
\hline 6 & $\begin{array}{l}\text { Saya mengakui kelemahan yang saya dan bersedia } \\
\text { menerima saran yang diberikan. }\end{array}$ & 125 & 99 & 79,2 & Setuju \\
\hline 7 & $\begin{array}{l}\text { Saya memberikan hasil kerja yang terbaik walaupun } \\
\text { imbalan/gaji yang diterima menurut saya tidak sesuai. }\end{array}$ & 125 & 101 & 80,8 & $\begin{array}{l}\text { Sangat } \\
\text { Setuju }\end{array}$ \\
\hline 8 & $\begin{array}{l}\text { Saya menyelesaikan tugas/kewajiban saya terlebih } \\
\text { dahulu, baru meminta dan menuntut hak saya. }\end{array}$ & 125 & 99 & 79,2 & Setuju \\
\hline 9 & $\begin{array}{l}\text { Saya mau menerima kritik dan saran dari rekan kerja, } \\
\text { yang berhubungan dengan nilai-nilai yang saya } \\
\text { yakini. }\end{array}$ & 125 & 105 & 84 & $\begin{array}{l}\text { Sangat } \\
\text { Setuju }\end{array}$ \\
\hline 10 & $\begin{array}{l}\text { Saya mau meningkatkan hasil kerja untuk } \\
\text { memperbaiki kelemahan di dalam melakukan } \\
\text { pekerjaan, sesuai dengan saran yang diberikan rekan } \\
\text { kerja. }\end{array}$ & 125 & 107 & 85,6 & $\begin{array}{l}\text { Sangat } \\
\text { Setuju }\end{array}$ \\
\hline
\end{tabular}

\section{Keterangan :}

$\begin{array}{ll}0,00 \%-20,00 \% & =\text { Sangat Tidak Setuju } \\ 20,01 \%-40,00 \% & =\text { Tidak Setuju } \\ 40,01 \%-60,00 \% & =\text { Biasa Saja } \\ 60,01 \%-80,00 \% & =\text { Setuju } \\ 80,01 \%-100,00 \% & =\text { Sangat Setuju }\end{array}$


Rekapitulasi hasil pernyataan terhadap Variabel Kinerja pada perusahaan industri di Bandar Lampung

Tabel 3Pernyataan tentang Kinerja

\begin{tabular}{|c|l|c|c|c|c|}
\hline No. & \multicolumn{1}{|c|}{ Pertanyaan } & Max & Riil & $\%$ & Kategori \\
\hline 1 & $\begin{array}{l}\text { Dalam pelaksanaan audit dan penyusunan } \\
\text { laporannya, auditor menggunakan kemahiran } \\
\text { profesionalnya dengan cermat dan seksama. }\end{array}$ & 125 & 110 & 88 & $\begin{array}{l}\text { Sangat } \\
\text { Setuju }\end{array}$ \\
\hline 2 & $\begin{array}{l}\text { Dalam melaksanakan pekerjaan, auditor } \\
\text { berpegang pada standar professional yang tinggi. }\end{array}$ & 125 & 108 & 86,4 & $\begin{array}{l}\text { Sangat } \\
\text { Setuju }\end{array}$ \\
\hline 3 & $\begin{array}{l}\text { Auditor selalu berpedoman pada standar auditing } \\
\text { dalam menjalankan tanggung jawab/tugasnya. }\end{array}$ & 125 & 103 & 82,4 & $\begin{array}{l}\text { Sangat } \\
\text { Setuju }\end{array}$ \\
\hline 4 & $\begin{array}{l}\text { Auditor memiliki komitmen yang kuat untuk } \\
\text { menyelesaikan audit dalam waktu yang tepat. }\end{array}$ & 125 & 98 & 78,4 & Setuju \\
\hline 5 & $\begin{array}{l}\text { Tugas-tugas yang dibebankan kepada auditor } \\
\text { dapat diselesaikan semuanya. }\end{array}$ & 125 & 95 & 76 & Setuju \\
\hline 6 & $\begin{array}{l}\text { Pekerjaan yang dibebankan kepada auditor, } \\
\text { selalu diselesaikan tepat waktu. }\end{array}$ & 125 & 93 & 74,4 & Setuju \\
\hline 7 & $\begin{array}{l}\text { Auditor datang dan pulang tepat waktu, ke kantor } \\
\text { tempat auditor bekerja. }\end{array}$ & 125 & 97 & 77,6 & Setuju \\
\hline 8 & $\begin{array}{l}\text { Auditor tidak mengambil waktu istirahat } \\
\text { melebihi yang dizinkan. }\end{array}$ & 125 & 89 & 71,2 & Setuju \\
\hline 9 & $\begin{array}{l}\text { Mau membantu rekan lain yang beban kerjanya } \\
\text { berlebih. }\end{array}$ & 125 & 96 & 76,8 & Setuju \\
\hline 10 & \begin{tabular}{l} 
Mau membantu auditor yang baru. \\
\hline
\end{tabular} & 125 & 102 & 81,6 & $\begin{array}{l}\text { Sangat } \\
\text { Setuju }\end{array}$ \\
\hline
\end{tabular}

\section{Keterangan :}

$0,00 \%-20,00 \%=$ Sangat Tidak Setuju

$20,01 \%-40,00 \%=$ Tidak Setuju

$40,01 \%-60,00 \%=$ Biasa Saja

$60,01 \%-80,00 \%=$ Setuju

$80,01 \%-100,00 \%=$ Sangat Setuju

\section{Uji Validitas dan Uji Realibilitas}

\section{Uji Validitas}

Penelitian yang valid artinya bila terdapat kesamaan antara data yang terkumpul dengan data yang sesungguhnya terjadi pada objek yang diteliti. Nilai validitas masingmasing item pernyataan dapat dilihat pada nilai Corrected item-Total Correlation masingmasing pernyataan. Hasil dari penelitian ini valid.

\section{Uji Realibilitas}

Penelitian yang reliable bila terdapat kesamaan data dalam waktu yang berbeda. Untuk mencapai hal tersebut, dilakukan realibilitas dengan menggunakan metode Alpha Cronbach's diukur berdasarkan skala Alpha Cronbach's 0 sampai 1. Dan hasil yang di dapat dari penelitian ini reliabel. 


\section{Uji Asumsi Klasik}

\section{Uji Normalitas}

Uji normalitas data pendekatan Liliefors (Lo). Dengan ketentuan apabila penghitungan statistik < level of significant, maka distribusi data dianggap normal; dan sebaliknya.

\section{Uji Multikolinieritas}

Uji Multikolinieritas bertujuan untuk menguji apakah model regresi ditemukan adanya korelasi antar variabel bebas (independent variabel). Pendeteksian adanya problem multikol dapat melihat nilai torerance dan lawannya Variance Inflation Factor (VIF). Jika nilai variance inflation factor (VIF) tidak lebih dari 10 maka model terbebas dari multikolinieritas. Hasil analisis untuk menguji multikolinieritas diperoleh nilai Variance Inflation Factor (VIF) pada masing-masing variabel bebas adalah sebagai berikut

Tabel 4. Hasil Uji Multikolinieritas

\begin{tabular}{|c|c|c|}
\hline Variabel Bebas & Nilai VIF & Kriteria \\
\hline$\left(\mathrm{X}_{1}\right)$ & 2,06 & $<10$ \\
\hline$\left(\mathrm{X}_{2}\right)$ & 2,06 & $<10$ \\
\hline
\end{tabular}

Sumber : Pengolahan data primer, 2012

Berdasarkan Tabel di atas maka diperoleh besarnya nilai VIF adalah $<10$. Hal ini berarti model terbebas dari multikolinieritas.

\section{Uji Heteroskedastisitas}

Uji heteroskedastisitas bertujuan menguji apakah dalam model regresi terjadi ketidaksamaan Variance dari residual satu pengamatan ke pengamatan yang lain. Untuk mendeteksi ada tidaknya heterositas pada suatu model dapat dilihat dari pola gambar scatter plot model. Model dikatakan tidak heteroskedastisitas, apabila :

1. Penyebaran titik-titik data sebaiknya tidak berpola,

2. Titik-titik data menyebar diatas dan dibawah atau disekitar angka 0 ,

3. Titik-titik data tidak mengumpul hanya di atas atau di bawah saja.

\section{Uji Simultan}

Uji simultan dimaksudkan untuk melihat pengaruh bersama-sama kecerdasan emosional $\left(\mathrm{X}_{1}\right)$ dan kecerdasan spiritual $\left(\mathrm{X}_{2}\right)$ terhadap kinerja auditor. Uji simultan menggunakan Uji F. Hasil uji simultan dapat dilihat pada Tabel di bawah ini

Tabel 5. Hasil Uji Simultan Pengaruh Kecerdasan Emosional $\left(\mathrm{X}_{1}\right)$ dan Kecerdasan Spiritual $\left(\mathrm{X}_{2}\right)$ terhadap Kinerja Auditor (Y)

\begin{tabular}{|c|c|c|}
\hline Nilai F & $P$-value (sig.) & Ket \\
\hline 31,065 & 0,000 & $\begin{array}{c}P \text {-value }(\text { sig. })< \\
0,05\end{array}$ \\
\hline $\mathrm{R}^{2}=0.739$ & & \\
\hline
\end{tabular}


Berdasarkan Tabel di atas diperoleh nilai $\mathrm{F}=31,065$ dengan nilai $P$-value 0,000 . Nilai $P$-value $<0,05$, maka dapat disimpulkan ada pengaruh secara bersama-sama kecerdasan emosional $\left(\mathrm{X}_{1}\right)$ dan kecerdasan spiritual $\left(\mathrm{X}_{2}\right)$ terhadap kinerja auditor. Pada Tabel 35 di atas juga diperoleh besarnya koefisien diterminasi $\left(\mathrm{R}^{2}\right)=0,739$. Hal ini berarti kinerja auditor $73,9 \%$ ditentukan oleh kecerdasan emosional $\left(\mathrm{X}_{1}\right)$ dan kecerdasan spiritual $\left(\mathrm{X}_{2}\right)$, sedangkan sisanya $26,1 \%$ ditentukan oleh faktor lain yang tidak tercantum dalam model regresi.

\section{Uji Parsial}

Uji parsial bertujuan untuk melihat pengaruh secara parsial kecerdasan emosional $\left(\mathrm{X}_{1}\right)$ dan kecerdasan spiritual $\left(\mathrm{X}_{2}\right)$ terhadap kinerja auditor. Uji parsial dapat dilihat pada Tabel di bawah ini

Tabel 6.

Hasil Uji t untuk Melihat Pengaruh Secara Parsial Variabel Bebas terhadap Variabel Terikat

\begin{tabular}{|l|c|c|c|}
\hline Variabel & $\begin{array}{c}\text { Koefisien } \\
\text { Regresi }\end{array}$ & $\begin{array}{c}\mathrm{t}- \\
\text { hitung }\end{array}$ & $\begin{array}{c}P \text { - } \\
\text { value }\end{array}$ \\
\hline Konstanta & $-18,902$ & & \\
\hline$\left(\mathrm{X}_{1}\right)$ & 0,679 & 3,214 & 0,004 \\
\hline$\left(\mathrm{X}_{2}\right)$ & 0,634 & 2,711 & 0,013 \\
\hline
\end{tabular}

Sumber : Pengolahan data primer, 2012

Berdasarkan Tabel 38 di atas diperoleh persamaan regresi $\mathrm{Y}=$ $18,902+0,679 \mathrm{X}_{1}+0,634 \mathrm{X}_{2}$. Koefisien regresi baik kecerdasan emosional maupun kecerdasan spiritual adalah positif, artinya semakin baik kecerdasan emosional dan spiritual semakin baik kinerja auditor.

\section{a. Pengaruh Kecerdasan Emosional terhadap Kinerja Auditor}

Hasil analisis diperoleh nilai $\mathrm{t}=3,214$ dengan $p$-value $=0,004$. Nilai $p$-value ternyata $<0,05$, artinya ada pengaruh kecerdasan emosional terhadap kinerja auditor.

\section{b. Pengaruh Kecerdasan Spiritual terhadap Kinerja Auditor}

Hasil analisis diperoleh nilai $\mathrm{t}=2,711$ dengan $p$-value $=0,013$. Nilai $p$-value ternyata $<0,05$, artinya ada pengaruh kecerdasan spiritual terhadap kinerja auditor.

\subsection{Pembahasan}

Berdasarkan hasil analisis menunjukkan bahwa kecerdasan emosional dan kecerdasan spiritual berpengaruh positif terhadap kinerja auditor. Hal ini berarti pengaruh kecerdasan emosional dan kecerdasan spiritual merupakan faktor yang dapat menentukan kinerja.

Adanya pengaruh kecerdasan emosional terhadap kinerja disebabkan kecerdasan emosional merupakan keterampilan yang dapat mempengaruhi seseorang untuk berhasil dapat menhadapi tuntutan. Artinya orang yang memiliki kecerdasan emosional yang baik sudah tentu memiliki keterampilan untuk mencapai keberhasilan. Kecerdasan emosional juga ternyata dapat menumbuhkan motivasi diri. Motivasi diri merupakan salah satu dimensi kecerdasan emosional, motivasi diri adalah kemampuan untuk menyadari dan menggunakan sumber motivasi diri untuk menghadapi kegagalan dan berusaha untuk bangkit.

Motivasi diri dapat diperlihatkan dengan dorongan yang kuat untuk mencapai prestasi, optimisme, dan komitmen organisasi yang tinggi. Dorongan untuk mencapai prestasi yang tinggi sudah tentu mendorong seorang auditor untuk meningkatkan kinerja. Berdasarkan 
uraian di atas menunjukkan bahwa secara kecerdasan emosional merupakan faktor yang menumbuhkan motivasi. Motivasi yang mendorong seseorang untuk meningkatkan kinerja. Dengan demikian secara langsung ada pengaruh kecerdasan emosional terhadap kinerja, emosi memang sangat berpengaruh pada kinerja. Seseorang yang sedang emosional, tidak akan bisa berfikir dengan baik, betapapun tingginya IQ mereka. Auditor dengan EQ yang baik mempunyai kemampuan pribadi dan sosial seperti empati, disiplin diri, dan inisiatif sehingga akan menghasilkan kinerja yang lebih baik dibandingkan dengan auditor dengan EQ yang lebih rendah.

Faktor kedua yang mempengaruhi kinerja auditor adalah kecerdasan spiritual. Kecerdasan spiritual adalah kecerdasan untuk menghadapi dan memecahkan persoalan makna atau nilai, yaitu kercerdasan untuk menempatkan prilaku dan hidup kita dalam konteks makna yang lebih luas dan kaya, kecerdasan untuk menilai bahwa tindakan atau jalan hidup seseorang lebih bermakna dibandingkan yang lain. SQ adalah landasan yang diperlukan untuk memfungsikan IQ dan EQ secara efektif. Bahkan menurutnya SQ merupakan kecerdasan tertinggi manusia. Kecerdasan spiritual memberikan manusia moral, kemampuan menyesuaikan diri berdasarkan pengalaman dan cinta serta kemampuan setara.

Kaitannya dengan kinerja, seseorang yang memiliki kecerdasan spiritual baik menganggap pekerjaan sebagai sebuah rahmat sehingga dalam bekerja akan terdorong untuk melakukan dengan sungguh-sungguh. Mereka bekerja dengan penuh rasa syukur dari hati yang bersih dan tulus. Bekerja dengan sungguh-sungguh inilah yang dapat meningkatkan kinerja seseorang dalam menyelesaikan pekerjaan. Bagi seorang auditor ini sangat penting, karena bekerja dengan hati yang bersih dan tulus sudah tentu akan menghasilkan audit yang baik dan transparan tanpa dapat dipengaruhi oleh orang lain.

Selain itu, kecerdasan emosional mendorong seseorang (auditor) bekerja secara konsisten (istiqomah), kerendahan hati (tawadlu), berusaha dan berserah diri (tawakal), ketulusan/sincerety (keiklasan), totalitas (kaffah), keseimbangan (tawazun), dan integritas \& penyempurnaan (ihsan). Apabila faktor-faktor tersebut dapat terealisasi oleh seseorang auditor, maka dapat dipastikan kinerja auditor pasti baik.

\section{KESIMPULAN DAN SARAN}

\subsection{Kesimpulan}

Berdasarkan hasil analisis, maka dapat disimpulkan ada pengaruh kecerdasan emosional dan spiritual terhadap kinerja auditor. Semakin baik kecerdasan emosional dan spiritual, semakin baik kinerja auditor. Kecerdasan emosional dan spiritual memberikan kontribusi terhadap kinerja auditor adalah 73,9\% sedangkan sisanya 26,1\% ditentukan oleh faktor lain.

\subsection{Saran}

Berdasarkan kesimpulan maka disarankan

1) Auditor harus mempertahankan dan meningkatkan kecerdasan emosional dan spiritual. Hal ini dapat ditempuh dengan terus mengikuti pelatihan yang berhubungan dengan cara meningkatkan kecerdasan emosional dan spiritual.

2) Pihak lembaga secara berkala mengadakan pelatihan cara meningkatkan kecerdasan emosional dan spiritual. 


\section{DAFTAR PUSTAKA}

Agustian, Ary Gianjar. 2001. Emosional Spiritual Quotient (ESQ). Rahasia sukses Membangun Kecerdasan Emosional dan Spiritual. Penerbit ARGA, Jakarta.

Alwani, Ahmad.2007. Pengaruh Kecerdasan Emosional terhadap Kinerja Auditor pada kantor akuntan Publik di kota Semarang. Skripsi, Universitas Negeri Semarang, Http://digilib.unnes.ac.ic/gsdl/collect, diakses pada 14 September 2010.

Amin, Muhammad. 2008. Pengaruh Emosional Quotient dan Spiritual Quotient terhadap kinerja karyawan pemeliharaan PT.PERTAMINA EP Field Pendopo region Sumatera. Tesis. Magister Manajeman Universitas Sriwijaya, Palembang.

Anggraini, Novi. 2011. Analisis Pengaruh Kecerdasan Emosional terhadap Kinerja Auditor pada kantor BPKP di Bandar Lampung. Skripsi, Universitas Bandar Lampung.

Damayanti, Irma. 2007. Pengaruh tingkat SQ dan EQ Profesional Muda Jakarta di Divisi Pemasaran terhadap keputusannya untuk pindah kerja atau bertahan. Skripsi Universitas Airlangga, http://www.aadln.lib.unair.ac.id, diakses pada 17 September 2010

Friyanti, Rini. 2007. Pengaruh Kecerdasan Emosional terhadap kepemimpinan yang efektif di konsultan Manajemen wilayah X Sumatera Selatan dan Bangka Belitung. Tesis, Magister Manajemen Universitas Sriwijaya, Palembang.

Gardner, Lisa. 2005. The Relationship Between Emotional Intelligence and Occupational Stress Process. Thesis, Swinburne University, http://adt.lib.swin.edu.au, diakses pada 7 September 2010.

Goelman, Daniel. 2006. Emotional intelligence. PT.Gramedia Pustaka Utama, Jakarta.

Goelman, Daniel. 2005. Kecerdasan Emosional untuk mencapai Puncak Kinerja. PT.Gramedia Pustaka Utama, Jakarta.

Goelman, Daniel. 1995. Working with Emotional Intelligence. Bloomsberry, London.

Hasibuan, Malayu S.P. 2000. Manajemen Sumber Daya Manusia. Edisi Revisi. Penerbit Bumi Aksara, Jakarta.

Malthis dan Jackson. 2006. Manajemen Sumber Daya Manusia. Penerbit Salemba Empat, Jakarta

Mayer, Henri. 2007. Manajemen dengan kecerdasan Emosional. Penerbit Nuansa, Bandung.

Penceliah, Yogi. 2003. Emotional intelligence for public Manager/Administratorrs to meet the Challenges of the future, Journal, University of Durban-Westville, South Africa, http://unpanl.un.org/intradoc, diakses pada 8 November 2010. 